\title{
Antioxidative Activity of Methanolic and Water Extracts from the Hyperthermophilic Archaeon Aeropyrum pernix $\mathrm{K} 1$
}

\author{
Mihaela Skrt, ${ }^{1}$ Polona Jamnik ${ }^{1}$ and Nataša Poklar Ulrih ${ }^{1,2, *}$ \\ ${ }^{1}$ Department of Food Science and Technology, Biotechnical Faculty, University of Ljubljana, Jamnikarjeva 101, 1000 \\ Ljubljana, Slovenia \\ ${ }^{2}$ Centre of Excellence for Integrated Approaches in Chemistry and Biology of Proteins (CipKeBiP), Jamova 39, 1000 \\ Ljubljana, Slovenia \\ *Corresponding author: E-mail: poklar.natasa@bf.uni-lj.si \\ Tel: +386-1-3203780; Fax: +386-1-2566296
}

Received: 18-08-2017

\begin{abstract}
The hyperthermophilic archaeon Aeropyrum pernix has adapted to optimal growth under high temperatures in saline environments and under oxidizing conditions. In the present study, we focused on the antioxidative activity of proteins from A. pernix K1. Following high temperature methanol and water extractions of the protein from the biomass of A. pernix $\mathrm{K} 1$, the total sulphydryl groups and radical scavenging activities were investigated. The total protein in the methanolic extract was $36 \%$ lower and showed $10 \%$ fewer sulphydryl groups than that from the water extract. However, the radical scavenging activity of the water extract was four-fold greater than for the methanolic extract. The proteins of both of these extracts were separated by two-dimensional electrophoresis, and selected proteins were identified using mass spectrometry. The majority of these identified proteins were intracellular proteins, such as those involved in oxidative stress responses and osmotic stress responses, and proteins with hydrolase and dehydrogenase activities. These proteins are also common to most organisms, and included putative uncharacterized proteins.
\end{abstract}

Keywords: Aeropyrum pernix K1, methanol/ water extraction, antioxidant activity, proteins

\section{Introduction}

Hyperthermophilic microorganisms have developed various mechanisms of molecular adaptation to survive at extreme temperatures of up to $105^{\circ} \mathrm{C}$, and also under oxidizing conditions. Adaptations to proteins to maintain their activities under these conditions are therefore crucial for the survival of hyperthermophiles. ${ }^{1}$ However, in comparison to bacteria and eukaryotes, relatively little is known about the molecular mechanisms of the responses to extreme conditions of hyperthemophilic archaea.

Most aerobes have multiple pathways for the detoxification of reactive oxygen species, and most of these include synthesis of superoxide dismutase (SOD), which catalyzes the conversion of superoxide radicals to oxygen and hydrogen peroxide. The mechanisms responsible for oxidative stress responses have been only partially defined in some archaea. Among the aerobic hyperthermophilic archaea, SODs have been reported for Pyrobaculum aerophilum and Aeropyrum pernix. ${ }^{2,3}$ From genomic sequence data, it has been suggested that the majority of aerobic hyperthermophilic archaea use a SOD-peroxyredoxine (Prx) system. ${ }^{4}$ The Prxs are thioldependent peroxidases that catalyze the detoxification of various peroxide substrates, such as $\mathrm{H}_{2} \mathrm{O}_{2}$, peroxinitrite, and hydroperoxides, and that control some signal transduction pathways in eukaryotic cells. ${ }^{5}$ Prxs are present in all cellular organisms, and they represent a ubiquitous family of antioxidant enzymes.

In 2005, the structure of an archaeal Prx from the aerobic hyperthermophilic crenarchaeon A. pernix $\mathrm{K} 1$ was reported, and a new oxidation mechanism of active oxygen removal by an antioxidant protein was defined. This oxidation reaction occurs through a novel 
mechanism, in which cysteine and neighboring histidine residues form a sulfurane derivative that acts as a reaction intermediate. ${ }^{5}$ An archaeal antioxidant Dps-like protein that can oxidize $\mathrm{Fe}(\mathrm{II})$ to $\mathrm{Fe}(\mathrm{III})$ using $\mathrm{H}_{2} \mathrm{O}_{2}$ as an oxidant was characterized from the hyperthemophilic acidophile Sulfolobus solfataricus. ${ }^{6}$ In a recent study of hyperthermophilic microorganisms, the Thermococcus kodakarensis KOD1 proteome response to unstable environment conditions was analyzed, and 42 proteins were up-regulated in response to to oxidative stress. ${ }^{7}$ For superoxide dismutase from $A$. pernix $\mathrm{K} 1$, this enzyme was shown to be tolerant to organic media. ${ }^{8}$ Such discoveries make hyperthermophilic organisms a very interesting source for various industrial applications. ${ }^{9-12}$

Aeropyrum pernix $\mathrm{K} 1$ is a strictly aerobic hyperthermophilic archaeon that grows optimally from 90 ${ }^{\circ} \mathrm{C}$ to $95{ }^{\circ} \mathrm{C}$, and although the proteome of $A$. pernix $\mathrm{K} 1$ was analyzed in 2006, little is known about its enzymatic and nonenzymatic antioxidant systems. ${ }^{11,12-14}$ Such hyperthermophilic organisms might be good sources for various compounds that have great potentional for biotechnological applications.

The aim of the present study was to compare the antioxidative activities of extracts obtained from A. pernix using two different solvents, as methanol and water, and to identify the compounds responsible for the antioxidative activities of these extracts. The extracts were analyzed for total sulfhydryl groups using Ellman's reagent, and antioxidant activity was measured using 1,1-diphennyl-2picryl-hydrazil (DPPH). The proteins from both of these extracts were analyzed by two-dimensional (2-D) gel electrophoresis, and some of them were identified by mass spectrometry.

\section{Experimental}

\section{1. Growth Media and Preparation of the Crude Extracts}

The archaeon A. pernix $\mathrm{K} 1$ was cultivated at $92{ }^{\circ} \mathrm{C}$ according to Milek et al.. ${ }^{15}$ The biomass was harvested at the late exponential growth phase, and washed with $20 \mathrm{mM}$ HEPES, $\mathrm{pH} 7.0,3 \% \mathrm{NaCl}$. The biomass was then resuspended in $50 \%$ aqueous methanol or in water (using Milli-Q water). After shaking for $2 \mathrm{~h}$ at $75^{\circ} \mathrm{C}$, the methanol/ water phase was recovered by centrifugation at $10,000 \times g$ for $10 \mathrm{~min}$. The extract was evaporated to dryness under reduced pressure at $45{ }^{\circ} \mathrm{C}$. The residue obtained was dissolved in Milli-Q water and analyzed as described below.

\section{2. Total Protein of Archaeal Biomass}

The total protein of the archaeal biomass was determined according to the Stickland method ${ }^{16}$, with a few modifications. Briefly, $0.5 \mathrm{~mL} 3 \mathrm{M} \mathrm{NaOH}$ was added to $1.0 \mathrm{~mL}$ of the appropriate resuspended biomass. The samples were kept at $100{ }^{\circ} \mathrm{C}$ for $5 \mathrm{~min}$, and following

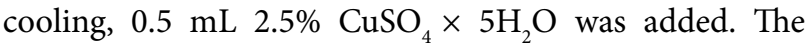
samples were mixed and incubated at room temperature for $5 \mathrm{~min}$ and then centrifuged in a benchtop centrifuge at $1,300 \times g$ for $10 \mathrm{~min}$. The absorbance of the supernatant was measured at $555 \mathrm{~nm}$, against a blank sample prepared with Milli-Q water instead of the resuspended biomass. Bovine serum albumin (Sigma-Aldrich) was used as the protein standard.

\subsection{Determination of Protein Concentrations in Extracts}

The protein concentrations of the crude methanolic and water extracts were determined by the method of Bradford, using a commercial dye reagent with bovine serum albumin (Sigma-Aldrich) as the standard for the protein calibration curves. ${ }^{17}$

\section{4. Radical Scavenging Activity Using the DPPH Assay}

Prior to the DPPH assay, the residues from the methanolic and water extractions were diluted with Milli-Q water to the same concentration of residue (mg) per milliliter water. The radical scavenging activity was determined according to a slightly modified method of Brand-Williams et al.. ${ }^{18}$ Briefly, the DPPH radical was prepared in methanol to a final concentration of $0.1 \mathrm{mM}$. Then $50 \mu \mathrm{L}$ samples were added to $1.45 \mathrm{~mL} 0.1 \mathrm{mM} \mathrm{DPPH}$ radical solution, and kept in the dark for $30 \mathrm{~min}$. The control sample was prepared in the same way, using $50 \mu \mathrm{L}$ Milli-Q water instead of the sample solution. The absorbance at $517 \mathrm{~nm}, A_{517}$, was recorded with a spectrophotometer (UV-VIS, model 8453; Hewlett-Packard). The absorbance of the samples and the control were measured against a methanol blank, and the scavenging activity was calculated according to following equation, and expressed as antioxidant potential (AOP):

$$
A O P(\%)=\frac{\left(A_{517 \text { controt }}-A_{517 \text { sample }}\right)}{A_{517 \text { control }}} \times 100
$$

where $A_{51 \text { control }}$ and $A_{517 \text { sample }}$ are the measured absorbances of the control and the sample, respectively.

\section{5. Quantitative Determination of Total Sulfhydryl Groups}

The total sulfhydryl groups were determined in the crude methanol and water extracts according to the Ellman method $^{19}$, with slight modifications. Briefly, mixtures of $200 \mu \mathrm{L}$ extract, $800 \mu \mathrm{L} 100 \mathrm{mM}$ phosphate buffer (pH 8.0) and 16.7 $\mu \mathrm{L} 10.0 \mathrm{mM}$ Ellman's reagent (5,5'-dithiobis-2nitrobenzoic acid; DTNB; Sigma-Aldrich), were mixed 
and left at room temperature for $5 \mathrm{~min}$ in the dark. The absorbance at $412 \mathrm{~nm}$ was then measured against a blank sample, using a spectrophotometer (HP 8453; Hewlett Packard). The concentrations of sulfhydryl groups were calculated according to the following formula:

$$
C_{S H}=\frac{A_{412}}{\varepsilon \times l} \times D
$$

where $\mathrm{C}_{\mathrm{SH}}$ is the molar concentration of the total thiol groups $(\mathrm{mol} / \mathrm{L}), A_{412}$ is the measured absorbance at 412 $\mathrm{nm}, \varepsilon$ is the molar absorption coefficient of TNB $(13,600$ $\left.\mathrm{M}^{-1} \mathrm{~cm}^{-1}\right), l$ is the optical path length $(\mathrm{cm})$, and $D$ is the dilution factor. The total thiol group ( $\mathrm{SH}$ ) content was expressed in $\mu \mathrm{mol} \mathrm{SH} / \mathrm{g}$ dry extract.

\section{6. Two-dimensional Electrophoresis}

Prior to 2-D gel electrophoresis, $50-\mu \mathrm{L}$ aliquots of the methanolic and water extracts were appropriately diluted with Milli-Q water and treated using 2-D CleanUp kits (GE Healthcare), according to the manufacturer instructions.

The 2-D electrophoresis was performed according to Görg ${ }^{20}$, with minor modifications. Briefly, the samples (100 $\mu \mathrm{g}$ protein) were mixed with rehydration solution (7 $\mathrm{M}$ urea, $2 \mathrm{M}$ thiourea, 2\% CHAPS, 2\% immobilized $\mathrm{pH}$ gradient [IPG] buffer [pH 4-7], $18 \mathrm{mM}$ dithiothreitol, and a trace of bromphenol blue), and applied to $13-\mathrm{cm}$ IPG pH 4 to 7 strips (GE Healthcare). After rehydration, a first dimension of isoelectric focusing was carried out at $20{ }^{\circ} \mathrm{C}$ (Multiphore II apparatus; GE Healthcare), according to the following voltage program: $300 \mathrm{~V}$ (gradient over $1 \mathrm{~min}$ ), $300 \mathrm{~V}$ (fixed for $1 \mathrm{~h}$ ), 3,500 V (gradient over $1.5 \mathrm{~h}$ ) and 3,500 V (fixed for $5 \mathrm{~h}$ ). Prior to the second dimension of the 2-D electrophoresis, the IPG strips were equilibrated for $15 \mathrm{~min}$ in sodium dodecyl sulfate (SDS) equilibration buffer $(75 \mathrm{mM}$ Tris/ $\mathrm{HCl}, \mathrm{pH} 8.8,6 \mathrm{M}$ urea, $30 \%$ glycerol, $2 \% \mathrm{SDS}$, and a trace of bromphenol blue) containing $1 \%$ dithiothreitol, and then containing $4.8 \%$ iodoacetamide for an additional $15 \mathrm{~min}$. The second dimension (SDS polyacrylamide gel electrophoresis) was carried out with $12 \%$ running gels on a vertical discontinuous electrophoretic system (SE 600; Hoeffer Scientific Instruments), at a constant $20 \mathrm{~mA} /$ gel for $15 \mathrm{~min}$, and then at a constant $40 \mathrm{~mA} /$ gel until the bromphenol blue reached the bottom of the gel. The 2-D gels were stained with SYPRO Ruby (Invitrogen), and then documented using a CAM-GX-CHEMI HR system (Syngene). The gels were run as triplicates. To align the gels, the 2-D Dymension software (Syngene) was used.

\section{7. Protein Identification}

Randomly chosen protein spots were excised from the gels and analyzed by liquid chromatography-tandem mass spectrometry (LC-MS/MS) using an ESI-TRAP instrument at the University of Aberdeen (Aberdeen Proteomics). The Mascot software was used to search the NCBInr 20091002 database. The taxonomy search parameter was Archaea (Archaeobacteria), and the tryptic digest was applied with a maximum number of one missed cleavage. The peptide mass tolerance was set to $\pm 1.5 \mathrm{Da}$, and the fragment mass tolerance to $\pm 0.5 \mathrm{Da}$. Additionally, carbamidomethylation of Cys and oxidation of Met were considered as possible fixed and variable modifications, respectively.

\section{8. Bioinformatic Analyses}

Similarity searching was carried out with Uniprot using BLAST (UniProt: http://www.uniprot.org). Orthology was investigated using the Kyoto Encyclopedia of Genes and Genomes (KEEG) database (Unipro; http://www.uniprot. org). Multiple sequence alignments were performed using the CLUSTAL Omega program (http://www.ebi.ac.uk/ Tools $/ \mathrm{msa} /$ clustalo/). ProtParam was used to analyze the amino-acid compositions (http://www.expasy.org/cgi-bin/ protparam). NetPhos 2.0 was used to predict Ser, Thr, and Tyr phosphorylation sites (http://www.cbs.dtu.dk/services/ NetPhos/). Conserved domains within protein sequences were defined using the NCBI CD server (http://www. ncbi.nlm.nih.gov/Structure/cdd/wrpsb.cgi). The domain organization of protein sequences was searched using the Pfam database (http://pfam.sanger.ac.uk/).

\section{Results and Discussion}

\section{1. Antioxidant Activity, and Total Protein and Sulfydryl Groups}

To determine the antioxidative activity of the hyperthermophilic archaeon A. pernix K1, the extracts were prepared using two different solvents: $50 \%$ aqueous methanol, and water at high temperature $\left(75^{\circ} \mathrm{C}\right)$. The antioxidant activities of these methanolic and water extracts were determined according to the free radical DPPH method, and are expressed as antioxidant potencial (AOP). The AOP of the methanolic and water extracts were $4.9 \%$ and $20.3 \%$, respectively (Table 1 ).

The total protein content in the A. pernix $\mathrm{K} 1$ biomass was $473( \pm 5) \mathrm{mg} / \mathrm{g}$ dry biomass. This biomass was used for the preparation of the methanolic and water extracts, with the total protein of the methanolic and water extracts of $0.115 \mathrm{mg} / \mathrm{mg}$ dry extract and $0.318 \mathrm{mg} / \mathrm{mg}$ dry extract, respectively (Table 1).

The total free sulfhydryl groups in the methanolic extracts was $0.092 \mu \mathrm{mol} \mathrm{SH} / g$ dry extract, and in water extracts, $1.10 \mu \mathrm{mol} \mathrm{SH} / \mathrm{g}$ dry extract (Table 1).

Organisms have complex systems of enzymatic (e.g., superoxide dismutase, peroxidase) and nonenzymatic (e.g., ascorbic acid, flavonoids, glutathione) antioxidant defense systems against harmful effects of free radicals 
and other oxidants. ${ }^{21}$ Antioxidant properties of natural sources have been reported mostly from higher plants ${ }^{22}$, with few reports carried out for hyperthermophilic organisms. ${ }^{2,3,6,23,24}$

To determine the antioxidant activities of the present biological samples, extraction is the first step, where the choice of the solvent for the extraction is of particular importance. Here, the AOP of the water extract was fourfold greater than that of the methanolic extract (Table 1). As no classical biosynthetic pathways of polyphenols have been annotated for the hyperthermophilic A. pernix, and some antioxidant enzymes, such as $\mathrm{SOD}^{3}$ and $\mathrm{Prx}^{5}$ are already known for hyperthermophilic archea, we assumed that the higher AOP of the water extract would correlate to protein content. Therefore, we focused on the protein (Table 1).

Furthermore, the total free sulfhydryl groups were determined for both extracts, and this was higher for the water extract (Table 1). This might be explained in terms of the greater water solubility of sulfhydryl compounds, and also their contribution to AOP, although further studies are needed to confirm this.

Table 1. Protein, sulfhydryl groups, and radical scavenging activity of the crude methanolic and water extracts.

\begin{tabular}{lccc}
\hline $\begin{array}{l}\text { Crude } \\
\text { extract }\end{array}$ & $\begin{array}{c}\text { Total protein } \\
\text { (mg/mg } \\
\text { dry extract) }\end{array}$ & $\begin{array}{c}\text { Total } \\
\text { sulfhydryl } \\
\text { group }(\boldsymbol{\mu m o l} / \mathbf{g} \\
\text { dry extract) }\end{array}$ & $\begin{array}{c}\text { Antioxidative } \\
\text { potential } \\
(\%)\end{array}$ \\
\hline Methanolic & $0.115 \pm 0.003$ & $0.092 \pm 0.001$ & $4.9 \pm 0.5$ \\
Water & $0.318 \pm 0.003$ & $1.10 \pm 0.03$ & $20.3 \pm 0.1$ \\
\hline
\end{tabular}

\section{2. Two-dimensional and LC-MS/MS Analysis of the Protein of the Extracts}

The protein of the crude methanolic and water extracts was analyzed using 2-D electrophoresis (Figure 1). Eleven randomly chosen proteins from the methanolic extract and 19 from the water extract were identified using LC-MS/MS (Tables 2, 3). The molecular masses (theoretical) of the proteins were in the range of 15,360 $\mathrm{Da}$ (Q9Y9S7) to 60,392 Da (Q9Y9J7), and the isoelectric points (pIs) (theoretical) for all of the proteins identified were $<7.0$, with the exception of the elongation factor Q9YAV0, and the putative dehydrogenase Q9YDK1, with pIs of $c a .9$.

A scheme of the gene locations in the genome of $A$. pernix was constructed using the BioNumerics software (version 7.6.1; Applied Maths), from which it can be seen that the genes listed in Table 2 and Table 3 are scattered around the genome (Supplementary Figure 1).

The majority of the proteins identified from these extracts of A. pernix $\mathrm{K} 1$ were intracellular proteins, and for better clarity they were classified into six different subgroups: proteins involved in oxidative stress responses; proteins involved in osmotic stress responses; proteins with hydrolase activities; dehydrogenases; proteins common to most organisms; and putative uncharacterized proteins.

\section{2. 1. Proteins Involved in Oxidative Stress responses}

Thiol peroxidase and superoxide dismutase were identified in the methanolic and water extracts, which are known to have roles in responses to oxidative stress. Protein spot ID2 from the methanol and water extracts
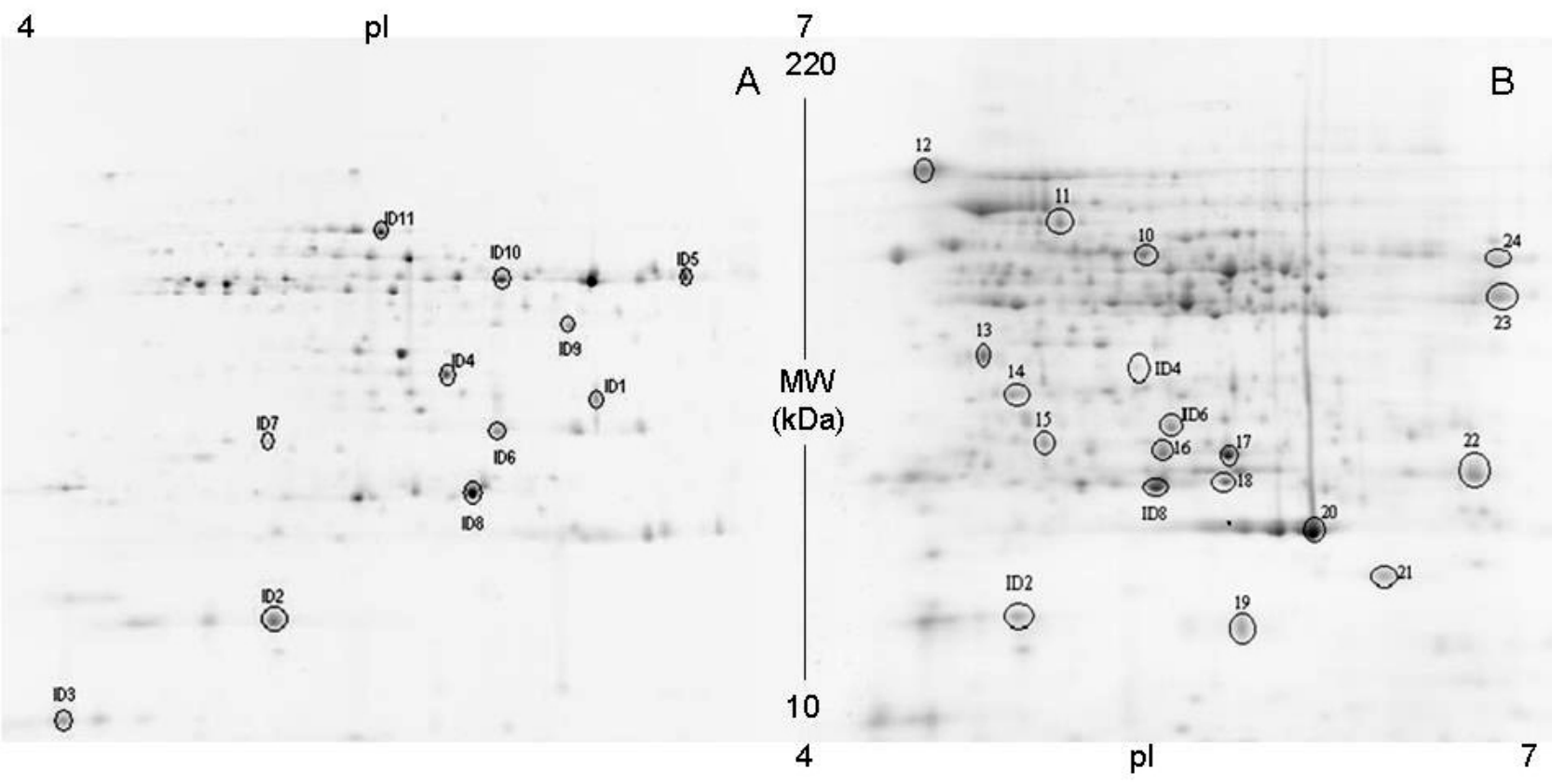

Figure 1. Representative two-dimensional protein profiles from the crude methanol extract (A) and the crude water extract (B) from A. pernix K1 grown at $\mathrm{pH} 7$ and $92{ }^{\circ} \mathrm{C}$. The proteins in the circled spots were identified by LC/MS-MS. Circled spots marked with ID 4 to 8 indicate the same proteins identified that were in both extracts. 
Table 2. Protein from the spots from the crude methanol extract identified by LC-MS/MS and through searches with the NCBInr database. ${ }^{a}$ Data from NCBI, ${ }^{\mathrm{b}}$ Accession number in the UniProtKB database.

\begin{tabular}{|c|c|c|c|c|c|c|c|c|c|}
\hline $\begin{array}{l}\text { Protein } \\
\text { spot } \\
\text { ID }\end{array}$ & Protein & $\begin{array}{l}\text { Accession } \\
\text { number }^{\mathrm{a}}\end{array}$ & ORF $^{\mathrm{a}}$ & $\begin{array}{l}\text { Transcript } \\
\text { ID }^{\mathrm{a}}\end{array}$ & $\begin{array}{c}\text { Accession } \\
\text { number }^{\mathrm{a}}\end{array}$ & $\begin{array}{c}\text { Theoretical } \\
\mathbf{M}_{\mathrm{r}}(\mathrm{Da})\end{array}$ & pI & $\begin{array}{l}\text { Mascot } \\
\text { score }\end{array}$ & $\begin{array}{c}\text { Sequence } \\
\text { coverage } \\
(\%)\end{array}$ \\
\hline 1 & Malate dehydrogenase & gi|116062469 & APE_0672.1 & BAA79645.2 & Q9YEA1 & 33469 & 6.06 & 996 & 69 \\
\hline 2 & Thiol peroxidase & gi|116063062 & APE_2125.1 & BAA81136.2 & Q9YA14 & 18532 & 5.33 & 305 & 77 \\
\hline 3 & Hypothetical protein & gi|116063103 & APE_2211.1 & BAA81223.2 & Q9Y9S7 & 15358 & 5.10 & 794 & 82 \\
\hline 4 & $\begin{array}{l}\text { Polyamine } \\
\text { aminopropyltransferase }\end{array}$ & gi|116062511 & APE_0767.1 & BAA79745.2 & Q9YE02 & 35595 & 5.66 & 722 & 47 \\
\hline 5 & $\begin{array}{l}\text { NADP-dependent } \\
\text { glutamate dehydrogenase }\end{array}$ & gi|116062758 & APE_1386.1 & BAA80383.2 & Q9YC65 & 46142 & 6.42 & 593 & 51 \\
\hline 6 & $\begin{array}{l}\text { Succinyl-CoA ligase } \\
\text { [ADP-forming] subunit alp }\end{array}$ & $\begin{array}{l}\text { gi|} 116062642 \\
\text { ha }\end{array}$ & APE_1072.1 & BAA80057.2 & Q9YD40 & 30934 & 5.77 & 680 & 71 \\
\hline 7 & Hypothetical protein & gi| 116062760 & APE_1388.1 & BAA80385.2 & Q9YC63 & 31969 & 5.20 & 388 & 23 \\
\hline 8 & $\begin{array}{l}\text { UPF0173 metal- } \\
\text { dependent hydrolase APE_ }\end{array}$ & $\begin{array}{l}\text { gi|5104787 } \\
1117\end{array}$ & APE_1117 & BAA80102.1 & Q9YCZ5 & 25927 & 5.70 & 733 & 42 \\
\hline 9 & $\begin{array}{l}\text { Succinyl-CoA } \\
\text { synthetase beta chain }\end{array}$ & gi|116062641 & APE_1065.1 & BAA 80050.2 & Q9YD47 & 41519 & 6.00 & 539 & 24 \\
\hline 10 & $\begin{array}{l}\text { NADP-dependent } \\
\text { glutamate dehydrogenase }\end{array}$ & gi|116062758 & APE_1386.1 & BAA80383.2 & Q9YC65 & 46142 & 6.50 & 578 & 19 \\
\hline 11 & Carboxypeptidase & gi|116062910 & APE_1775.1 & BAA 80778.2 & Q9YB20 & 57988 & 5.50 & 613 & 19 \\
\hline
\end{tabular}

Table 3. Protein spots from the crude water extract identified by LC-MS/MS and through searches with the NCBInr database. ${ }^{\mathrm{a}} \mathrm{Data}$ from NCBI,

${ }^{\mathrm{b}}$ Accession number in the UniProtKB database.

\begin{tabular}{|c|c|c|c|c|c|c|c|c|c|}
\hline $\begin{array}{l}\text { Protein } \\
\text { spot } \\
\text { ID }\end{array}$ & & $\begin{array}{c}\text { Accession } \\
\text { number }^{\mathrm{a}}\end{array}$ & ORF $^{a}$ & $\begin{array}{l}\text { Transcript } \\
\text { ID }^{\mathrm{a}}\end{array}$ & $\begin{array}{c}\text { Accession } \\
\text { number }^{\mathrm{a}}\end{array}$ & $\begin{array}{c}\text { Theoretical } \\
M_{r}(D a)\end{array}$ & pI & $\begin{array}{l}\text { Mascot } \\
\text { score }\end{array}$ & $\begin{array}{c}\text { Sequence } \\
\text { coverage } \\
(\%)\end{array}$ \\
\hline 2 & Thiol peroxidase & gi|116063062 & APE_2125.1 & BAA81136.2 & Q9YA14 & 18770 & 5.33 & 248 & 71 \\
\hline 4 & $\begin{array}{l}\text { Polyamine } \\
\text { aminopropyltransferase }\end{array}$ & gi| 116062511 & APE_0767.1 & BAA79745.2 & Q9YE02 & 35595 & 5.66 & 622 & 43 \\
\hline 6 & $\begin{array}{l}\text { Succinyl-CoA ligase } \\
\text { [ADP-forming] subunit alph }\end{array}$ & $\begin{array}{l}\text { gi| } 116062642 \\
\text { ha }\end{array}$ & APE_1072.1 & BAA80057.2 & Q9YD40 & 30934 & 5.77 & 897 & 73 \\
\hline 8 & $\begin{array}{l}\text { UPF0173 metal-dependent } \\
\text { hydrolase APE_1117 }\end{array}$ & gi|5104787 & APE_1117 & BAA80102.1 & Q9YCZ5 & 25927 & 5.72 & 556 & 56 \\
\hline 10 & Glutamine synthetase & gi|116063069 & APE_2142.1 & BAA81153.2 & Q9Y9Z7 & 50743 & 5.61 & 667 & 49 \\
\hline 11 & $\begin{array}{l}\text { NADP-depended } \\
\text { glyceraldehyde-3-phosphate }\end{array}$ & $\begin{array}{l}\text { gi|116062915 } \\
\text { dehydrogenase }\end{array}$ & APE_1786.1 & BAA80789.2 & Q9YB09 & 56162 & 5.58 & 1314 & 63 \\
\hline 12 & $\begin{array}{l}\text { NADP-depended } \\
\text { glyceraldehyde-3-phosphate }\end{array}$ & $\begin{array}{l}\text { gi|116062915 } \\
\text { dehydrogenase }\end{array}$ & APE_1786.1 & BAA80789.2 & Q9YB09 & 56162 & 5.58 & 794 & 33 \\
\hline 13 & $\begin{array}{l}\text { Putative } \\
\text { methylcobalamin: homocyst }\end{array}$ & $\begin{array}{l}\text { gi| } 116063025 \\
\text { teine methyltran }\end{array}$ & $\begin{array}{l}\text { APE_2050.1 } \\
\text { nsferase }\end{array}$ & BAA81060.2 & Q9YA89 & 36553 & 5.13 & 928 & 68 \\
\hline 14 & $\begin{array}{l}\text { Thermosome beta } \\
\text { subunit }\end{array}$ & gi|116063040 & APE_2072.1 & BAA81083.2 & Q9YA66 & 60392 & 5.34 & 499 & 16 \\
\hline 15 & $\begin{array}{l}\text { Putative sugar-phosphate } \\
\text { nucleotidyl transferase }\end{array}$ & gi|5105992 & APE_2291 & BAA81303.1 & Q9Y9J7 & 26747 & 5.41 & 531 & 48 \\
\hline 16 & $\mathrm{ABC}$ transporter & gi| 116062880 & APE_1688.1 & BAA80689.2 & Q9YBA9 & 30466 & 6.04 & 470 & 39 \\
\hline 17 & $\mathrm{ABC}$ transporter & gi| 116062880 & APE_1688.1 & BAA80689.2 & Q9YBA9 & 30466 & 6.04 & 669 & 51 \\
\hline 18 & $\begin{array}{l}\text { Deoxyribose phosphate } \\
\text { aldolase }\end{array}$ & gi|116063194 & APE_2437.1 & BAA81452.2 & Q9Y948 & 24497 & 6.00 & 592 & 57 \\
\hline 19 & $\begin{array}{l}\text { Putative uncharacterized } \\
\text { protein }\end{array}$ & gi|116062872 & APE_1660.1 & BAA80661.2 & Q9YBD7 & 16607 & 6.63 & 376 & 56 \\
\hline 20 & $\begin{array}{l}\text { Superoxide dismutase } \\
{[\mathrm{Mn} / \mathrm{Fe}]}\end{array}$ & gi|5104403 & APE_0741 & BAA79718.1 & Q9Y8H8 & 24562 & 6.50 & 746 & 74 \\
\hline 21 & $\begin{array}{l}\text { Putative uncharacterized } \\
\text { protein }\end{array}$ & gi|5106093 & APE_2389 & BAA81404.1 & Q9Y996 & 20683 & 8.17 & 376 & 40 \\
\hline 22 & Putative dehydrogenase & gi|5104581 & APE_0912 & BAA79896.1 & Q9YDK1 & 27807 & 9.04 & 726 & 69 \\
\hline 23 & Elongation factor 1-alpha & gi| 5105535 & APE_1844 & BAA 80848.1 & Q9YAV0 & 48632 & 9.22 & 835 & 40 \\
\hline 24 & Elongation factor 1-alpha & gi| 5105535 & APE_1844 & BAA80848.1 & Q9YAV0 & 48632 & 9.22 & 625 & 39 \\
\hline
\end{tabular}


was identified as thiol peroxidase (Q9YA14), which contains three Cys residues. The NCBI CD database ${ }^{25}$ search indicated a specific hit for the protein to have a conserved PRX_alkyl-hydroperoxide-reductase-(Ahp)E-like domain, so the protein appears to belong to the Prx family, with a greater similarity to the 2-Cys class of Prxs. The Prxs are thiol-specific antioxidant proteins with peroxidase activity, whereby hydrogen peroxide, peroxinitrate, and organic hydroperoxides are reduced using equivalents derived from thioredoxin, glutathione, trypanothione, and AhpF. The 2-Cys class of Prxs use cellspecific disulfide oxidoreductases to reduce the disulfide bond formed between the oxidized peroxidatic Cys $\left(\mathrm{C}_{\mathrm{p}}\right.$ $\mathrm{SOH}$ ) intermediate and the second redox-active Cys, the resolving Cys $\left(\mathrm{C}_{\mathrm{R}}-\mathrm{SH}\right){ }^{5}{ }^{5}$ The Prxs have been described for all cellular organisms. The sequence similarity search (UniProtKB, Blast) for protein thiol peroxidase (Q9YA14) showed $63 \%$ indentity with $\mathrm{AhpC} / \mathrm{thiol}$-specific antioxidant (A4WK54) from the Archaea Pyrobaculum arsenaticum (strain DSM 13514/ JCM 11321), and 63\% identity with bacterioferritin comigratory protein homolog (Q8ZUL0) from the Archaea P. aerophilum. Both of these proteins belong to the $\mathrm{AhpC} /$ thiol-specific antioxidant protein family. AhpC directly reduces organic hyperoxides into the reduced dithiol form. Thiol-specific antioxidants are physiologically important antioxidants that constitute an enzymatic defense against sulfur-containing radicals. ${ }^{26}$

Protien spot ID20 from the water extract was identified as SOD (Q9Y8H8) (Table 3). SODs catalyze the disproportion of superoxide into hydrogen peroxide and oxygen. The $S O D$ gene of $A$. pernix was first cloned and expressed in Escherichia coli in 1999. ${ }^{3}$ A. pernix SOD was shown to be cambialistic, active with either $\mathrm{Mn}$ or Fe, and more thermostabile with $\mathrm{Mn}$. The molecular weight of this soluble enzyme was $24.5 \mathrm{kDa}$, with a pI of $6.5 .^{3}$ Based on the finding that SOD from hyperthermophilic A. pernix $\mathrm{K} 1$ is stable also in organic solvents ${ }^{8}$, we hypothesized that the antioxidative activity of methanol extracts would be higher than for the water extracts, but this was not confirmed in our study.

\section{2. 2. Proteins Involved in Osmotic Stress Responses}

Aeropyrum pernix is hyperthemophilic archaeon that grows optimally in a salinity of $3.5 \%$, and therefore it must be able to adjust to alterations in salt concentrations in the environment. In the methanolic extract, we identified a hypothetical protein with accession number Q9Y9S7, that might be involved in responses to osmotic stress. The sequence similarity searches for this putative uncharacterized protein, ID3 (Q9Y9S7), showed that it appeared to be related to the osmotically induced protein $\mathrm{C}$ (OsmC) family of proteins. OsmC is a stressinducible protein that has been identified in $E$. coli, and it is involved in the intracellular defense mechanisms against oxidative stress caused by exposure to elevated osmolarity. ${ }^{27}$ This protein family also contains an organic hydroperoxide detoxification protein that has a novel pattern of oxidative stress regulation. ${ }^{28}$ The $\mathrm{Pfam}^{29}$ database searches also indicated that protein Q9Y9S7 from the hyperthermophilic $A$. pernix $\mathrm{K} 1$ has a conserved domain that is shared with the OsmC family. Multiple sequence alignments with the Clustal Omega program ${ }^{30}$ were carried out for Q9Y9S7 and several archaeal OsmC proteins (Figure 2). These findings showed two conserved Cys residues in all of the aligned sequences. The OsmC family from mesophilic and thermophilic organisms has been shown to have two conserved Cys residues. ${ }^{31}$ Q9Y9S7 from the hyperthermophilic A. pernix K1 contains these two conserved Cys residues at amino-acid positions 63 and 115, and three Cys residues have been shown for the hyperthermophilic Thermococcus kokadakaraensis KOD1, and for Pyrococcus horikoshii OT3 and Pyrococcus furiosus DSM 3638. The OsmC protein from the hyperthermophilic T. kokadakaraensis KOD1 was identified as a protein
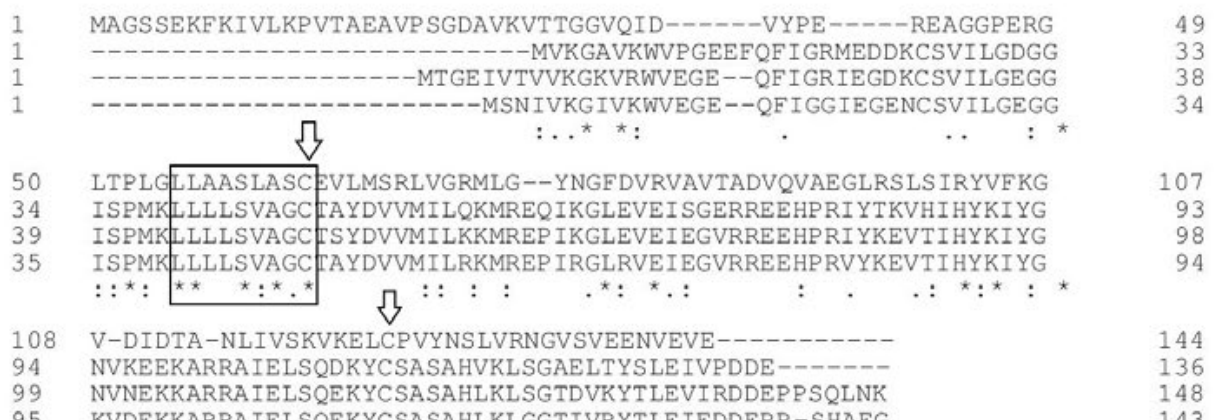

NVNEKKARRAIELSQEKYCSASAHLKLSGTDVKYTLEVIRDDEPPSQLNK

KVDEKKARRAIELSQEKYCSASAHLKLGGTIVRYTLEIFDDEPP -SHAEG . . * * . : * * : ${ }^{\star}$ : : : : :

Figure 2. Multiple sequence alignment for Q9Y9S7 and several hyperthermophilic archaeal OsmC homologs. The origins of the sequences were as follows: hyperthermophilic T. kodakaraensis KOD1 (Q5JFM5), P. horikoshii OT-3 (O59138; NP_143334) and P. furiosus DSM 3638 (Q8U141; NP_579117). The alignment was constructed using the Clustal Omega program. Residues are marked according to the following criteria: ${ }^{\star}$, identical residues; colon (:), residues with conserved substitutions; full stop (.), residues with semi-conserved substitutions; $\Rightarrow$, conserved Cys residues; numbers at the ends of each line (right-hand side), numbers of amino-acid residues. 


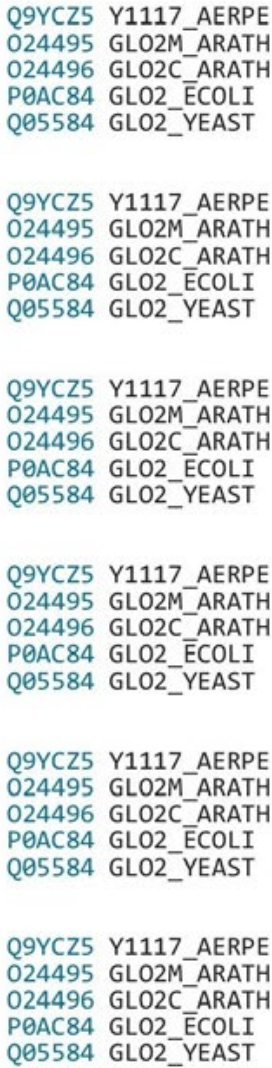

1
1
1
1
1

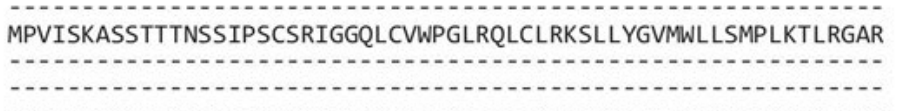

- MA- - RLTYLG-HAA- - FQLEAGGRKILVDPWLSNPKSPV KTLKITHFCSISNMPSSLKIEL - - - VPCSKDNYAYLLHDEDTGTVGVVDPSEAAPVIEA - . - - VPCLQDNYSYLIIDESTGDAAVVDPVDPEKVIAS - MNLNS - - IPAFDDNYIWVLNDE - AGRCLIVDPGDAEPVLNA MQVKSIKMRWESGGVNYCYLLSDSKNKKSWLIDPAEPPEVLPE $::^{* *}$

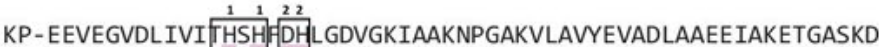
LS-RKNWNL TYILNTHHHDDHIGGNAELKERYG - ..-A-KV-

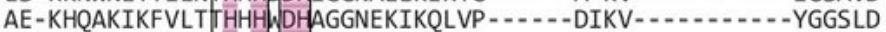

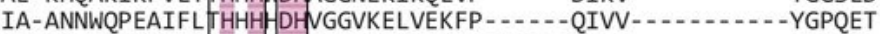

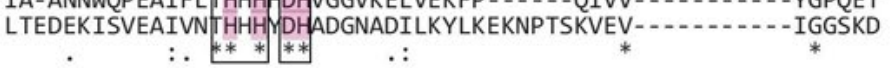

94 ELFNAGRVIGA-NIGGPVVLQDLGLKVAFTPATHS- . 158 KDRIPGIDILLKDSDKWMF-AGHEVRILDTPGHTQGHISFYFPGS-- - -ATIFTGDLIYS - -KVKGCTDAVDNGDKLTLGODINILALHTPCHTKGHISYYVNGKEGENPAVFTGDTLFV - -QDKGTTQWKDGETA-FVLGHEFSVIATPGHTLGHICYFSK - . - . -PYLFCGDTLFS CPK - - -VTIIPENLKKL -HLGDLEITCIRTPCHTRDSICYYVKDPTTDERCIFTGDTLFT :

TGEGRVYHAGDTGVTMDMRLVGE IY - - - - - KPHVALLPIGGHFTMDPVEAAKAVELIRP LSCGTLSEG - - TPEQMLSSLQ-KIVSL - - - -PDDTNIYCGRENTAGNLKFALSVE - - -P AGCGKFFEG - - TAEQMYQSLCVTLAAL - - - - -PKPTQVYCGHEYTVKNLEFALTVE - - - P GGCGRLFEG - - TASOMYOSLK -KLSAL - . - - -PDDTLVCCAHEYTLSNMKFALSIL - - -P AGCGRFFEG - - TGEEMDIALNNSILETVGRQNWSKTRVYPGHEYTSDNVKFVRKIY- - $\mathrm{P}$
$* .$.
$*$

LVAIPMHYGTFPVLYGDPEEFKKRVEEKCLPTQVRILKPGESYE -F- - - - - -DFSKA- - - . - KNETLQSYATR - VAH- - - LRSOGLPSIPTTVKVEKACNPFLRISSKDIRKSLSI - . - NNGKIQQKLAW-ARQ- - -QRQADLPTIPSTLEEELETNPFMRVDKPEIQEKLGC - - - - HDLSINDYYRK - VKE - - - LRAKNQITLPVILKNERQINVFLRTEDIDLINVINE - - - - QVGENKALDEL -EQF---CSKHEVTAGRFTLKDEVEFNPFMRLEDPKVQKAAGD

Figure 3. Multiple sequence alignment for Q9YCZ5 from A. pernix K1 and several proteins with known functions from zinc metallo-hydrolases group 2 (glyoxalase II), representing the hydroxyacylglutathione hydrolases (EC 3.1.2.6). Sequences: UPF0173 metal-dependent hydrolase from $A$. pernix K1 (Q9YCZ5); GLX2-1 from Arabidopsis thaliana (O24495, mitochondrial); GLX-2 from A. thaliana (O24496); gloB from E. coli (strain K12P0AC84); and GLO2 from Saccharomyces cerevisiae (Q05584). The alignment was constructed using the Clustal Omega program. *, identical residues; colon (:), residues with conserved substitutions; full stop (.), residues with semi-conserved substitutions; boxes with marks 1 and 2 , residues that coordinate zincs 1, 2, respectively; numbers at the ends of each line (right-hand side), numbers of amino-acid residues.

that is overexpressed in response to osmotic stress, but not under heat and oxidative stress, and it can act as an organic and inorganic hydroperoxide peroxidase at high temperatures. ${ }^{32}$ All of these database searches indicated that the protein Q9Y9S7 from A. pernix $\mathrm{K} 1$ should be an OsmC-like protein.

\section{2. 3. Proteins With Hydrolase Activity}

Protein spot ID8 (Q9YCZ5) was identified as the UPF0173 metal-dependent hydrolase, a member with an unidentified protein function. The Pfam database searches revealed that protein Q9YCZ5 has a lactamase B domain and it is a member of the metallo- $\beta$-lactamase superfamily. The $\beta$-lactamases are enzymes that hydrolyse $\beta$-lactam antibiotics and are responsible for the resistance of some bacteria to $\beta$-lactam antibiotics. ${ }^{32}$ The metallo- $\beta$-lactamases are class $\mathrm{B} \beta$-lactamases that require $\mathrm{Zn}^{2+}$ for their function, with members distributed over three domains of living organisms: Eukarya, Archaea, and Bacteria. ${ }^{33,34}$ Most members of this superfamily share five conserved motifs, the most characteristic of which is a His-X-His-
$\mathrm{X}$-Asp-His signature. ${ }^{28}$ The family members include class B $\beta$-lactamase, thiolesterases, members of the glyoxalase II family, an mRNA 3'-processing protein, a DNA crosslink-repair enzyme, and a DNA-uptake-related protein, and as such, their sequences are highly divergent. ${ }^{34}$ These proteins belong to the zinc metallo-hydrolase family of the $\beta$-lactamase fold. Based on their biological functions, the members of the zinc metallo-hydrolase family have been classified into 16 groups. ${ }^{34}$ Some of these include one $\mathrm{Zn}^{2+}$ per molecule or require a binuclear active site, or they can have two iron ions per molecule. ${ }^{35,36-38}$ Multiple sequence alignments with the Clustal Omega program were carried out for Q9YCZ5 from A. pernix K1 and several proteins with known functions from the zinc metallo-hydrolases group 2 (glyoxalases II) ${ }^{34}$ These revealed four of five highly conserved segments that are found in glyoxalases II (Figure 3). Glyoxalases II catalyze hydrolysis of the thiolester of S-D-lactoglutathione to produce glutathione and D-lactic acid, and they include two $\mathrm{Zn}^{2+}$ per molecule for their catalytic activity. ${ }^{39}$ The UniProt database search for the alignment of the individual proteins (excluding Q9YCZ5) showed that His and Asp are the amino-acid residues that 
bind two $\mathrm{Zn}^{2+}$ per subunit (Figure 3). Sequence alignments of Q9YCZ5 with glyoxalases II revealed that Q9YCZ5 has four highly conserved amino-acid residues: His49, His51, Asp53, and His54, which are also possible binding sites for $\mathrm{Zn}^{2+}$. The ratio of total negatively charged aminoacids to positively charged amino-acids was in favor of the negatively charged residues in all of the aligned aminoacid sequences. The calculated pIs with the ProtParam program for the aligned proteins were from 5.43 (GLO2 ECOLI) to 6.14 (GLO2M_ARATH), with 5.72 for Q9YCZ5 from A. pernix K1. It can thus be concluded that this hypothetical protein, Q9YCZ5, from A. pernix K1 is related to the glyoxalases II, although this protein family shows sequence similarity to class B $\beta$-lactamase. ${ }^{40}$ As such, protein Q9YCZ5 from A. pernix K1 might also have a role in detoxification of glycolysis by-products.

Protein spot ID11 (Q9YB20) from the crude methanol extract was identified as the protein with the highest molecular weight, of 57,988 Da. Q9YB20 is a carboxypeptidase(EC3.4.24)withmetallocarboxypeptidase activity. These carboxypeptidases catalyze the hydrolysis of C-terminal amino-acids from polypeptide chains by a mechanism in which water acts as the nucleophile, one or two metal ions hold the water molecule in place, and the charged amino-acid side chains are ligands for the metal ions. The known metal ligands are His, Glu, Asp, and/or Lys, and at least one other residue is required for catalysis, which might have an electrophilic role. Of the known metalloproteases, around 50\% of them contain an HEXXH motif. ${ }^{41}$ According to the MEROPS peptidase database (http://merops.sanger.ac.uk/about/index.shtml), Q9YB20 from $A$. pernix $\mathrm{K} 1$ belongs to the M32 peptidase family and the carboxypeptidase Taq family, with the MEROPS name for Q9YB20 of carboxypeptidase Pfu. M32 family members contain two $\mathrm{Zn}^{2+}$-binding His residues and a catalytic Glu residue in a HEXXH $\mathrm{Zn}^{2+}$-binding motif, a motif that is most commonly found in zinc endopeptidases and aminopeptidases. ${ }^{42}$ The third $\mathrm{Zn}^{2+}$ ligand is a Glu that is in a HES motif, further towards the C-terminus of the carboxypeptidase Taq family. Carboxypeptidase Taq is a $\mathrm{Zn}^{2+}$-containing thermostable metallopeptidase. ${ }^{43}$ The ScanProsite ${ }^{44}$ (http://www.expasy.ch/tools/scanprosite/) sequence searches for Q9YB20 from A. pernix K1 revealed an AVIHEFGHAL motif as a $\mathrm{Zn}^{2+}$-binding region between amino-acids 265 and 274. Carboxypeptidase Pfu was originally isolated and purified from the hyperthermophilic archaeon P. furiosus, and it was characterized as a cobaltactivated carboxypeptidase. ${ }^{45}$

\section{2. 4. Dehydrogenases}

Dehydrogenases acting on $\mathrm{CH}-\mathrm{OH}$ or $\mathrm{CH}-\mathrm{NH}_{2}$ groups of donors were identified in the methanolic and water extracts. Protein spot ID1 was identified as malate dehydrogenase (MDH; accession number Q9YEA1; MDH_AERPE; EC 1.1.1.37), with 69\% sequence coverage.
Sequence similarity searches showed that this protein belongs to the lactate dehydrogenase (LDH)/ $\mathrm{MDH}$ superfamily and the MDH type 3 family. The FASTA ${ }^{46}$ sequence for Q9YEA1 revealed no Cys and Trp among the 308 amino acids. MDH_AERPE is an intracellular oxidoreductase, and it has been shown that it has a specificity for $\mathrm{NADP}^{+}\left(\mathrm{K}_{\mathrm{M}}, 0.019 \mathrm{mM}\right)$ over the $\mathrm{NAD}^{+}$coenzyme $\left(\mathrm{K}_{\mathrm{M}}\right.$, $0.12 \mathrm{mM}$ ) for (S)-malate oxidation, and unlike $\mathrm{MDH}$ from other sources, it can readily catalyze tartrate oxidation. MDH_AERPE is a homotetrameric protein with a molecular mass of about $110 \mathrm{kDa} \cdot{ }^{47}$ Homotetrameric MDH has also been characterized from the hyperthermophilic Archaea Methanocaldococcus jannaschii, and from a dimer MDH from the hyperthermophilic Archaea Arhaeoglobus fulgidus; the dimer MDH from A. fulgidus lacks the sequence that mediates the dimer-dimer interaction. ${ }^{48}$ Structural comparisons of MDHs have revealed that the hyperthermostability of MDH_AERPE appears to be attributable to its smaller cavity volume and larger number of ion pairs and ion-pair networks. ${ }^{47}$

Protein Q9YC65 from the methanolic extract (an NADP-dependent glutamate dehydrogenase) was identified in two spots, spot ID5 and spot ID10, with slightly different pIs, of 6.42 and 6.50, respectively, but the same molecular masses (Figure 1, Table 1). This might have resulted from post-translational modifications, such as glycosylation, phosphorylation or proteolytic cleavage, which have been seen to occur with proteins in Archaea. ${ }^{49}$ We used different tools for posttranslational modification predictions, and the only positive posttranslation modification for Q9YC65 was detected with NetPhos 2.0 $0^{50}$ : Ser, Thr, and Tyr phosphorylation. Altogether, eight Ser, eight Thr, and five Tyr were predicted for posttranslational phosphorylation, with the highest scores for Ser116 (0.994), Ser395 (0.995), Thr43 (0.865), and Tyr147 (0.994).

We also identified an unusual member of the shortcahin dehydrogenase/ reductase (SDR) family proteins: putative dehydrogenase, identified from water extracts (protein spot ID22). This dehydrogenase from A. pernix is unusual because of a unique catalytic triade of Ser-Ser-Arg, instead of the usually present catalytic triad composed of Ser-Tyr-Lys in the other SDR family proteins. ${ }^{51,52}$

In the sample obtained from the water extract, some common dehydrogenases of the Calvin cycle were identified in protein spots ID11 and ID22 (Table 3).

\section{2. 5. Proteins Common to Most Organisms}

Some proteins that can be found in all known organisms were also identified in these spots: ID4, ID6, ID10, ID13, ID15, ID16, ID17, ID18, ID23, and ID24, and their identification characteristics are summarized in Table 3. They participate in biosynthetic processes, such as amino-acid synthesis (ID13), polyamine synthesis (ID4) and protein synthesis (ID23, ID24), and they are part of the TCA cycle (ID6) or the pentose phosphate pathway 
(ID18), or they are involved in substrate uptake and export, like ABC transporters (ID16, ID17). Various substratebinding proteins from the $\mathrm{ABC}$ transporter family have already been identified in archaeon $A$. pernix $\mathrm{K} 1$ using a proteomic approach. ${ }^{53}$

\section{2. 6. Putative Uncharacterized Proteins}

Three putative uncharacterized proteins were identified in protein spots ID7, ID19, and ID20 (Tables 2, 3). The Pfam searches for protein ID7 defined two significant matches: one match was shared with the DUF1028 family of bacterial and archaeal proteins of unknown function, where some members are associated with a C-terminal peptidoglycan-binding domain; the other match found a putative peptidoglycan-binding domain shared with the peptidoglycan-binding-2 family. As archaeal cell walls lack peptidoglycan, and as some archaeal species have pseudopeptidoglycan ${ }^{54}$, it is more likely that this protein is involved in maintenance of surface structures.

The Pfam search for protein ID19 found that this protein has a CoA binding domain with a Rossmann fold where the cofactor $\mathrm{NAD}^{+}$binds.

Putative uncharacterized protein Q9Y996 has a DUF35 oligonucleotide/ oligosaccharide-binding (OB)fold domain, a domain with unknown function that is conserved in hypothetical archaeal and bacterial proteins. The OB fold is at the C-terminal of the approximately 70-amino-acid-long domain..$^{55}$

\section{Conlusions}

Depite the low number of proteins identified in both of these extracts, those identified included some antioxidant proteins, such as SOD and thiol peroxidase, and a protein with a potential molecular function as a stress response, which might be responsible for the antioxidant activities of these extracts.

The antioxidative activity of the water extract was higher in comparison to that of the methanol extract, which indicates that the right selection of solvent is an important parameter in the preparation of A. pernix K1 biomass extracts with antioxidant activity.

\section{Acknowledgements}

This study was supported by the Ministry of Higher Education, Science and Technology of the Republic of Slovenia (Research program: Biochemical and Biophysical Characterization of Natural Compounds: P4-0121). The Aberdeen Proteome Facility is funded jointly by the Scottish Higher Education Funding Council (SHEFC), the Biotechnology and Biological Sciences Research Council (BBSRC), and the University of Aberdeen.

\section{References}

1. C. J. Reed, H. Lewis, E. Trejo, V. Winston, C. Evilia, Archaea 2013, Article ID 373275. DOI:10.1155/2013/373275

2. M. M. Whittaker, J. W. Whittaker, J. Biol. Inorg. Chem. 2000, 5, 402-408. DOI:10.1111/j.1432-1033.1968.tb00383.x

3. S. Yamano, Y. Sako, N. Nomura, T. Maruyama, J. Biochem. 1999, 126, 218-225.

DOI:10.1093/oxfordjournals.jbchem.a022426

4. E. Pedone, S. Bartolucci, G. Fiorentino, Front. Biosci. 2004, 9, 2909-2926. DOI:10.2741/1447

5. E. Mizohata, H. Sakai, E. Fusatomi, T. Terada, K. Murayama, M. Shirouzu, Y. Shigeyuki, J. Mol. Biol. 2005, 354, 317-329. DOI: $10.1016 /$ j.jmb.2005.09.006

6. B. Wiedenheft, J. Mosolf, D. Willits, M. Yeager, K. A. Dryden, M. Young, T. Douglas, Proc. Natl. Acad. Sci. U. S. A. 2005, 102, 10551-10556. DOI: 10.1073/pnas.0501497102

7. B. Jia, J. Liu, L. Van Duyet, Y. Sun, Y. H. Xuan, G.-W. Cheong, Front. Microbiol. 2015, 6: 605.

DOI:10.3389/fmicb.2015.00605

8. T. Nakamura, K. Torikai, K. Uegaki, J. Morita, K. Machida, A. Suzuki, Y. Kawata, FEBS J. 2011, 278, 598-609.

DOI: $10.1111 / \mathrm{j} .1742-4658.2010 .07977 . x$.

9. J. A. Littlechild, Arcahea, 2015, 2015, 10 pg. Article ID 14767 DOI:10.1155/2015/147671

10. M. Li, L. Zhu, W. Wang, SpringerPlus 2016, 5, 1-10.

DOI: $10.1186 / \mathrm{s} 40064-016-1854-9$

DOI:10.1186/s40064-016-1854-9

11. Y. Sako, N. Nomura, A. Uchida, Y. Ishida, H. Morii, Y. Koga, T. Hoaki, T. Maruyama, Int. J. Syst. Bacteriol. 1996, 46, 10701077. DOI: $10.1099 / 00207713-46-4-1070$

12. S. Yamazuki, J. Yamazuki, K. Nishijima, R. Otsuka, M. Mise, H. Ishikawa, K. Sasaki, S. I. Tago, K. Isono, Mol. Cell. 2006, 5, 811-823. DOI: $10.1074 /$ mcp.M500312-MCP200

13. G. Palmieri, A. Casbarra, I. Fiume, G. Catara, A. Capasso, G. Marino, S. Onesti, M. Rossi, Extremophiles 2006, 10, 393-402. DOI: $10.1007 / \mathrm{s} 00792-006-0508-1$

14. G. Palmieri, R. Cannio, I. Fiume, M. Rossi, G. Pocsfalvi, Mol. Cell. Proteomics 2009, 8, 2570-2581.

DOI: $10.1074 / \mathrm{mcp} . M 900012-\mathrm{MCP} 200$

15. I. Milek, B. Cigić, M. Skrt, G. Kaletunc, N, Poklar Ulrih, Can. J. Microbiol. 2005, 51, 805-809. DOI: 10.1139/w05-060

16. L. H. Stickland, J. Gen. Microbiol. 1951, 5, 698-703. DOI: $10.1099 / 00221287-5-4-698$. DOI:10.1099/00221287-5-4-698

17. M. M. Bradford, Anal. Biochem. 1976, 72, 248-254. DOI:10.1016/0003-2697(76)90527-3

18. W. Brand-Williams, M. E. Cuvelier, C. Berset, LWT-Food Sci. Technol. 1995, 28-30. DOI:10.1016/S0023-6438(95)80008-5

19. G. L. Ellman, Arch. Biochem. 1959, 82, 70-77. DOI:10.1016/0003-9861(59)90090-6

20. A. Görg, Nature 1991, 349, 545-546. DOI:10.1038/349545a0

21. S. Noori, Sci. Rep. 2012, 1, 1-9. DOI: $10.4172 /$ scientificreports. 413

22. M. S. Brewer, Compr. Rev. Food Sci. Food Saf. 2011, 10, 221247. DOI: $10.1111 /$ j.1541-4337.2011.00156.x 
23. S. J. Jeon, K. Ishikawa, J. Biol. Chem. 2003, 278, 24174-24180. DOI: $10.1074 /$ jbc.M300618200

24. M. V. Weinberg, F. E. Jr. Jenney, X. Cui, M. W. W. Adams, J. Bacteriol. 2004, 186, 7888-7895.

DOI: $10.1128 /$ JB.186.23.7888-7895.2004

25. A. Marchler-Bauer, S. Lu, J. B. Anderson, F. Chitsaz, M. K. Derbyshire, C. DeWeese-Scott, J.H. Fong, L. Y. Geer, R. C. Geer, N.R. Gonzales, M. Gwadz, D. I. Hurwitz, J. D. Jackson, Z. Ke, C. J. Lanczycki, F. Lu, G. H. Marchler, M. Mullokandov, M. V. Omelchenko, C. L. Robertson, J. S. Song, N. Thanki, R. A. Yamashita, D. Zhang, N. Zhang, C. Zheng, S. H. Bryant, Nucleic Acids Res. 2011, 39, D225-D229.

DOI: $10.1093 /$ nar/gkq1189

26. Z. A. Wood, E. Schroder, J. Robin Harris, L. B. Poole, Trends Biochem. Sci. 2003, 28, 32-40.

DOI:10.1016/S0968-0004(02)00003-8

27. S. Gordia, C. Gutierrez, Mol. Microbiol. 1996, 19, 729-736. DOI: 10.1046/j.1365-2958.1996.418945.x

28. S. Mongkolsuk, W. Praituan, S. Loprasert, M. Fuangthong, S, Chamnongpol, J. Bacteriol. 1998, 180, 2636-2643.

29. R. D. Finn, J. Mistry, J. Tate, P. Coggill, A. Heger, J. E. Pollington, O. L. Gavin, P.Gunasekaran, G. Ceric, K. Forslund, L. Holm, E. L. L. Sonnhammer, S. R. Eddy, A. Bateman, 2010, 38, D211-D222. DOI: 10.1093/nar/gkp985

30. F. Sievers, A. Wilm, D. Dineen, T. J. Gibson, K. Karplus, W. Li, R. Lopez, H. McWilliam, M. Remmert, J. Söding, J. D. Thompson, D. G. Higgins, Mol Syst Biol. 2011, 7, 1-6. DOI: $10.1038 / \mathrm{msb} .2011 .75$

31. S. C. Park, B. P. Pham, L. V. Duyet, B. Jia, S. Lee, R. Yu, S. W. Han, J. K. Yang, K. S. Hahm, G. W. Cheong, Biochim. Biophys. Acta 2008, 1784, 783-788. DOI: $10.1016 /$ j.bbapap.2008.02.002

32. M. I. Page, A. Badarau, Bioinorg. Chem. Appl. 2008, 2008, Article ID 576297. DOI:10.1155/2008/576297

33. C. Bebrone, Biochem. Pharmacol. 2007, 74, 1686-1701. DOI:10.1016/j.bcp.2007.05.021

34. H. Daiyasu, K. Osaka, Y. Ishino, H. Toh, FEBS Lett. 2001, 503, 1-6. DOI: 10.1016/S0014-5793(01)02686-2

35. J. A. Cricco, A. J. Vila, Curr. Pharm. Des. 1999, 5, 915-927.

36. C. Frazão, G. Silva, C. M. Gomes, P. Matias, R. Coelho, L. Sieker, S. Macedo, M. Y. Liu, S. Oliveira, M. Teixeira, A. V. Xavier, C. Rodrigues-Pousada, M. A. Carrondo, J. L. Gall, Nat. Struct. 2000, 7, 1041-1045. DOI:10.1038/80961

37. S. Y. Gu, X. X. Yan, D. C. Liang, Proteins 2008, 72, 531-536. DOI: $10.1002 /$ prot.22069

38. A. Yamamura, J. Ohtsuka, K. Kubota, Y. Agari, A. Ebihara, N. Nakagawa, K. Nagata, M. Tanokura, Proteins 2008, 73,
1053-1057. DOI: $10.1002 /$ prot.22215

39. A. D. Cameron, M. Ridderström, B. Olin, B. Mannervik, Structure 1999, 7, 1067-1078.

DOI:10.1016/S0969-2126(99)80174-9

40. A. F. Neuwald, J. S. Liu, D. J. Lipman, C. E. Lawrence, Nucleic Acids Res. 1997, 25, 1665-1677. DOI:10.1093/nar/25.9.1665

41. N. D. Rawlings, A. J. Barret, Methods Enzymol. 1995, 248, 183-228. DOI: 10.1016/0076-6879(95)48015-3

42. S. H. Lee, H. Taguchi, E. Yoskimura, E. Minagawa, S. Kaminogawa, T. Ohta, H. Matsuzawa, Protein Eng. 1996, 9, 467-469. DOI: $10.1093 /$ protein/9.6.467

43. S. H. Lee, H. Taguchi, E. Yoshimura, E. Minagawa, S. Kaminogawa, T. Ohta, H. Matsuzawa, Biosci., Biotechnol. 1994, 58, 1490-1495. DOI: 10.1271/bbb.58.1490

44. E. Castro, C. J. A. Sigrist, A. Gattiker, V. Bulliard, P. S. Langendijk-Genevaux, E. Gasteiger, A. Bairoch, N. Hulo, Nucleic Acids Res. 2006, 34, W362-W365.

DOI: $10.1093 /$ nar/gkl124

45. T. C. Cheng, V. Ramakrishnan, S. I. Chan, Protein Sci. 1999, 8, 2474-2486. DOI: $10.1110 /$ ps.8.11.2474

46. W. R. Pearson, D. J. Lipman, Proc. Natl. Acad. Sci. U. S. A. 1988, 85, 2444-2448. DOI:10.1073/pnas.85.8.2444

47. R. Kawakami, H. Sakuraba, S. Goda, H. Tsuge, T. Ohshima, Biochim. Biophys. Acta 2009, 1794, 1496-1504.

DOI: $10.1016 /$ j.bbapap.2009.06.014

48. D. Madern, C. Ebel, H. A. Dale, T. Lien, I. H. Steen, N. K. Birkeland, G. Zaccai, Biochemistry 2001, 40, 10310-10316. DOI: $10.1021 /$ bi010168c

49. J. Eichler, M. W. W. Adams, Microbiol. Mol. Biol. Rev. 2005, 69, 393-425. DOI: 10.1021/bi010168c

50. N. Blom, S. Gammeltoft and S. Brunak, J. Mol. Biol. 1999, 294, 1351-1362. DOI: 10.1006/jmbi.1999.3310

51. A. Yamamura, T. Ichimura, F. Mimoto, J. Ohtsuka, K. I. Miyazono, M. Okai, M. Kamo, W. C. Lee, K. Nagata, M. Tanokura, Proteins, 2008, 70, 1640-1645.

DOI: $10.1002 /$ prot. 21860

52. T. Tanabe, N. Tanaka, K. Uchikawa, T. Kabashima, K. Ito, T. Nonaka, Y. Mitsui, M. Tsuru, T. Yoshimoto, J. Biochem. 1998, 124, 634-641.

DOI:10.1093/oxfordjournals.jbchem.a022159

53. P. Jamnik, M. Meglen, P. Raspor, N. Poklar Ulrih, World J. Microbiol. Biotechnol. 2010, 26, 1579-1586.

DOI: $10.1007 /$ s11274-010-0333-7

54. O. Kandler, H. König, Cell. Mol. Life Sci. 1998, 54, 305-308. DOI: $10.1007 / \mathrm{s} 000180050156$

55. A. G. Murzin, EMBO J. 1993, 12, 861-867. 


\section{Povzetek}

Hipertermofilna arheja Aeropyrum pernix je prilagojena za življenje pri visokih temperaturah, v slanem okolju in pri oksidativnih pogojih. V tej raziskavi smo se osredotočili na antioksidativno aktivnost proteinov iz A. pernix K1. Proteine smo iz biomase $A$. pernix ekstrahirali v metanolu in vodi pri visoki temperaturi. $\mathrm{V}$ ekstraktih smo določili skupne tiolne skupine in antioksidativno učinkovitost. V metanolnem ekstraktu je bila vsebnost skupnih proteinov za $36 \%$ nižja kot v vodnem ekstraktu, prav tako je bilo za $10 \%$ manj določenih skupnih tiolnih skupin. Antioksidativna učinkovitost vodnega ekstrakta je bila štirikrat višja kot metanolnega. Proteine smo iz obeh ekstraktov ločili z dvodimenzionalno elektroforezo, izbrane proteine pa analizirali z masno spektrometrijo. Večina identificiranih proteinov sodi med intracelularne proteine, ki so vključeni v oksidativni in osmolarni stresni odgovor. Identificirani smo tudi nekaj proteinov s hidrolitično in dehidrogenazno aktivnostjo. 